\title{
Response of different chemical treatment on shelf-life and quality of tomato fruits (cv. GT-1) during storage in summer season
}

\author{
- H.J. Senjaliya*, R.P. RajPuT ${ }^{1}$, S.N. Galani ${ }^{1}$ and G.S. Mangaroliya ${ }^{1}$ \\ Department of Horticulture, Junagadh Agricultural University, JUNAGADH (GUJARAT) INDIA \\ ${ }^{1}$ Agriculture Research Station (Fruit Crops), Junagadh Agricultural University, Mahuva, BHAVNAGAR (GUJARAT) INDIA \\ Email : hjpate125@gmail.com \\ *Author for Correspondence \\ Research chronicle : Received : 11.11.2014; Revised : 01.04.2015; Accepted : 15.04.2015
}

\section{SUMMARY :}

The present investigation was carried out to study the response of different chemical treatment on shelf-life and quality of tomato fruits. The fruit samples were drawn and analysed periodically for various physical and bio-chemical changes. In summer results revealed that tomato fruits treated with post harvest treatments of $\mathrm{KMnO}_{4}+\mathrm{BLE}$ reduce ripening and gave maximum marketable fruits with increased shelf-life of tomato fruits. The minimum loss in weight was noted when tomato fruits treated with 2 per cent bael leaf extract. The fruits treated with $\mathrm{KMnO}_{4} 3000 \mathrm{ppm}+2$ per cent BLE increased the per cent marketable fruits with increase in storage period. Maximum shelf-life (10 days) was observed in fruits treated with $\mathrm{KMnO}_{4} 2000 \mathrm{ppm}+2$ per cent $\mathrm{BLE}$ and $\mathrm{KMnO}_{4} 2000$ ppm alone. Maximum acidity was recorded in $\mathrm{T}_{1}$ with 2 per cent bael leaf extract. Ascorbic acid content was highest with the post harvest application of $\mathrm{GA}_{3} 400 \mathrm{ppm}$ in combination with 2 per cent bael leaf extract. The fruits treated with $\mathrm{GA}_{3}$ increases TSS, reducing sugar and total sugar at initial and later stage of storage, but acidity was increased at later stage of storage. Maximum percentage of reducing and total sugar was recorded in control condition.

KEY WORDS : Tomato, Summer, Storage, Shelf-life, Bale leaf extract, $\mathrm{KMnO}_{4}, \mathrm{GA}_{3}$

How to cite this paper : Senjaliya, H.J., Rajput, R.P., Galani, S.N. and Mangaroliya, G.S. (2015). Response of different chemical treatment on shelf-life and quality of tomato fruits (cv. GT-1) during storage in summer season. Internat. J. Proc. \& Post Harvest Technol., 6 (1) : 1-5. 